\title{
Island fictions and metaphors in contemporary literature
}

\author{
Katrin Dautel \\ University of Malta \\ katrin.dautel@um.edu.mt \\ Kathrin Schödel \\ University of Malta \\ kathrin.schoedel@um.edu.mt
}

\begin{abstract}
In recent years, there has generally been an increasing scholarly interest in island literature. German-language literature and scholarship concerning it have proven highly relevant to the analysis of contemporary island literature, yet these are rarely recognised within English-language island studies publications. The editorial introduction to this special thematic section on Island Fictions and Metaphors in Contemporary Literature sets the stage for further analyses.
\end{abstract}

Keywords: contemporary literature, fiction, islands, metaphors

https://doi.org/10.24043/isj.40

(C) 2017 - Institute of Island Studies, University of Prince Edward Island, Canada.

\section{Theoretical discourses: island literature studies}

Recent island discourses have been characterised by constant re-negotiations, ranging from traditional constructs of the insular as spaces of isolation and backwardness to concepts of islands as places of interconnectedness and fluidity. The increasing discussion about the construction of insular spaces is also matched by a noticeable turn to island fictions and metaphors in international literature in general and in German-language literature in particular, employing the island metaphor as an image for socio-political or ontological conditions, challenging and deconstructing common ideas about island spaces and thus inventing and even establishing, one might say, new island myths. Scholarship of insular spaces both as geographical as well as metaphorical places situates island studies within the so-called spatial turn in literary and cultural studies over the past decades with its focus on the analysis of fictional spaces at the interface of cultural and social sciences. As Patrick Ramponi et al. $(2011$, p. 7) state in the preface to their edited volume on islands and archipelagos (Wilkens et al. 2011), islands not only traditionally serve as places of longing, but are also useful epistemological tools for the analysis of historically variable figures of thought. As will also be shown in the contributions to this special thematic section, literary constructions of the insular can unfold on two levels: on the one hand on a semantic level, that is the island being developed as metaphor for a number of topics such as existential or political issues, as manifestations or subversions of power structures and gender hierarchies, but on the other hand also on a textual level by turning the insular into a structural feature hinting at specific re-conceptions of (linguistic) islands through aesthetic constructions or referring to the process of writing itself.

A number of publications by German-language scholars have appeared in island literature studies over the past years, opening up a fruitful interdisciplinarity and offering a range of approaches. This means that the thematic section at hand deals with a highly topical subject and could even be considered as part of a specific Zeitgeist, emphasising the need for a discussion on the increase of insular spaces as a counterpoint to the 'dissolution' of space in current times of globalisation, in the context of which traditional concepts of space are intensely questioned. These 
recent publications deal with several aspects of the insular, ranging from the literary representation of a specific island or region, the literary representation of time structures in relation to insular spaces and the aesthetic construction of islands in poetry and prose as nissopoiesis. The following paragraphs shall provide a brief introduction to these developments in island literature studies in a German-language context.

Comparatist Christian Moser (2005, p. 408; our translation) wrote a seminal article which provides an analysis of "occidental island discourse" and outlines how the dominant Western conception of the island results from two contrasting pairs which shape its discursive construction. The opposition between island and mainland leads to the notion of the island as peripheral, secondary to or derived from the continent; it also influences the specific temporal imagination of the island as a-historical, disconnected from change and exchange and representing an 'original' stage (Moser, 2005, p. 408f.). The second fundamental opposition which shapes Western island discourses is that of land and sea, where the island appears as a clearly defined and easily controllable space with the sea as its boundary (Moser, 2005, p. 409). In this context, the island represents stability and closure in contrast to the changeable, open sea. Moser (p. 412), then, goes on to highlight alternative island conceptions to this predominant notion considering non-European contexts but also the occidental tradition itself in his study of three island texts - Homer's Odyssey, More's Utopia, and a chapter from Herder's Ideas on the Philosophy of the History of Mankind (Moser, 2005, pp. 413-432) -, whose constructions of open, hybrid and ambivalent islands he emphasises.

As mentioned above, in their edited volume on islands and archipelagos in literary and cultural studies, Anna Wilkens et al. (2011) show that the analytical instrument of the insular can be used in various ways, such as to explore the communicative function of archipelagos and islands (Ette, 2011), the historio-political view on Italy between fragmentation and unification through the representation of Sicily (König, 2011), or as a paradigmatic site for the relationship between the human and nature (Termeer, 2011).

Another relevant contribution to island literature studies dealing with the aesthetic dimension of literary island 'production' as nissopoiesis is provided by Daniel Graziadei, who, in his article in the recent handbook on space and literature (Dünne \& Günzel, 2015), discusses the construction of islands and island discourses through narrative structures, closely linked to their specific (textual) spatiality (Graziadei, 2015). Graziadei shows island production processes in two seminal island novels, namely Defoe's Robinson Crusoe and Farther Adventures, also taking into consideration postmodern and postcolonial Robinsonades by J.M. Coetzee and Patrick Chamoiseau in order to highlight the serial effect of island discourses and the risk of a perpetuation of colonial approaches, as well as the potential of deconstructing common discourses and establishing alternatives.

A recent German-language publication in the field of island literature studies which deals with the literary representation of a specific geographical area is the comprehensive volume Pazifikismus, edited by Johannes Görbert, Mario Kumekawa, and Thomas Schwarz (2016). The numerous contributions discuss the reception of Pacific islands in comparative literature and film from imaginative and real circumnavigations of the 18th century, figurations of 'pacificism' and exoticism, the Pacific in the colonial context as well as contemporary takes on the Pacific islands with a focus on German-language literature, such as the highly debated dystopian novel Imperium by Christian Kracht (2012).

Our own English-language volume Insularity: Representations and Constructions of Small Worlds (Dautel \& Schödel, 2016) explores and questions predominant uses of the metaphor of the insular in a wide range of articles in literary and cultural studies. These engage with the concept of insularity from various theoretical perspectives and analyse constructions and deconstructions of insular closure and autonomy, utopian insularity, the island as a microcosm and the boundary between land and sea in literature, film, fine art and video games as well as discourses of memory and national identity. Several of the contributions in this volume reflect the remarkable presence of island narratives in contemporary German-language literature (for example Bauer, 2016; Dautel, 2016). The papers by Valentina Serra (2017) and Oriana Schällibaum (2017) in the thematic 
section at hand also belong to this context and explore further aspects: Schällibaum offers an analysis of island novels by Raoul Schrott, which can be linked to other recent German-language island texts, such as Christian Kracht's Imperium (Bauer, 2016) or Judith Schalansky's Atlas of Remote Islands (Dautel, 2016). Whilst in the Insularity book Burggrabe (2016) analyses the construction of Sicily as an island "of the Between" in 20th century German-language literature, in this section, Serra (2017) focuses on Sardinia and the transformation of its myth in contemporary German-language literature. Interestingly, a recent publication in the volume Inseln (Islands) edited by Hans Richard Brittnacher studies the depiction of Capri in German-language literature from Goethe - who wrote about almost being shipwrecked near Capri in his famous Italian Journey but did not visit the island (May, 2017, p. 161) - to the contemporary author Arnold Stadler, in whose novel Komm, gehen wir (2007) Capri again appears as "the place of longing within the literary topography of Italy from a German perspective” (May, 2017, p. 176; our translation), which it had also been in Romantic imaginings, especially through the myth of the Blue Grotto (May, 2017, pp. 163-165).

This recent volume, Inseln (Brittnacher, 2017a), which was published in the series Projektionen. Studien zu Natur, Kultur und Film (Projections. Studies on Nature, Culture and Film) in edition text+kritik, is a collection of articles on various island fictions, especially in film, as for instance, on filmic depictions of Alcatraz (Heizmann, 2017), on Shutter Island (Pötzsche, 2017) or the series Lost (Spanke, 2017). The intriguing editorial introduction Die Insel. Idylle und Desaster (The Island: Idyll and Disaster) (Brittnacher, 2017b, pp. 10-13; our translation) deals with diverse island imaginings, but focuses on the predominant notion of the island as an opposite to the mainland. When Brittnacher writes, for example, that "islands belong more to nature than to history" and stresses a particular perception of time, linked to the tides of the ocean, as shared by all inhabitants of islands, he summarises existing island discourses but also seems to affirm their constructions of difference as general characteristics of the experience of geographical islands. Brittnacher asserts, for instance, that the "central definition of the island - any island! - is its remoteness." As a counterpoint to such insular isolation, he mentions the phenomenon of archipelagicity. Nevertheless, his overview of island discourses, which is also included in a recent special issue of the online journal literaturkritik.de about island literature (Brittnacher, 2017c, p. 16), foregrounds - and partly continues - romanticising "phantasies" of the island as a secluded, idyllic or dangerous space of otherness.

Islands as characterised by a specific temporality, which is also the topic of one of the contributions in the volume just discussed (Bauer, 2017), are at the core of the book Inseln und Insularitäten. Ästhetisierungen von Heterochronie und Chronotopie seit 1960 edited by Michael Ostheimer and Sabine Zubarik (2016a). In their preface, Ostheimer and Zubarik argue that the spatial otherness of islands has almost vanished in an age of globalisation when even the remotest island is connected to "networks of traffic and economy" (Ostheimer \& Zubarik, 2016b, pp. 8-10; our translation) so that, instead, a temporal otherness has become the focus of visions of the island as a space removed from the dictates of 'time management' and acceleration. At least in island fictions, this possibility of a 'heterochrony' remains imaginable. Following Bakhtin's theory of the 'chronotope', the authors seek to investigate the specific interrelation between space and time as well as (temporal) narrative patterns in the aesthetic construction of islands, the chronotope 'island-time' ('Inselzeit'). Besides this theoretical orientation, which is not only applied to literature, but also, for instance, to the phenomenon and discursive framing of off-shore financial centres, whose only seemingly insular temporality is analysed in relation to the general workings of global capitalism (Giacovelli \& Langenohl, 2016), the volume also has a strong focus on islands in a German-language context, namely, the use of the island in the literature, film, and fine art of the GDR. This is explored in particular with reference to the author and painter Matthias Wegehaupt, whose island novels Die Insel (Wegehaupt, 2005), which is based on earlier notes (Ostheimer \& Zubarik, 2016b, p. 14), and Schwarzes Schilf(Wegehaupt, 2011) connect the GDR era with contemporary Germany. The seven contributions about islands in Wegehaupt's works 
as well as in art and literature of the GDR present further examples for the relevance of island fictions and metaphors in a German-language context.

As shown in this brief overview, there is a noticeable turn to the island within Germanlanguage academic studies as well as in literature. This is also the topic of the second part of this thematic section on island fictions and metaphors in contemporary literature. The first part provides theoretical approaches, whereas the final part turns to island fictions as metaphors for socio-political realities.

\section{Island conceptions: island making processes and relationality}

The papers in the first part of this thematic section focus on an analysis of how predominant imaginings of the island are rejected, deconstructed, and countered in contemporary literature. This is placed in a tradition of island literature which offers different island conceptions highlighting the island's own changeability and openness and the interconnection, rather than clear opposition, between land and sea, emphasising the manifold perspectives on and from the island and its dynamic construction as opposed to a clear delimitation and fixity. This also reflects the general tendency of theories of space, since Lefebvre's (1974) The Production of Space, towards the analysis of spatial practices and the processual constitution of spaces. The island, then, becomes apparent, not as the clearly circumscribed and easily conquered space of colonialist island imaginings, but rather as a constantly re-created space with changing boundaries and inscriptions. This theoretical focus on the dynamic construction of island spaces - perhaps somewhat ironically - matches an increased awareness of the real changeability of the border between land and sea and the particular fragility of island spaces in times of climate change.

The two articles by the members of the Island Poetics Research Group, Daniel Graziadei, Britta Hartmann, Ian Kinane, Johannes Riquet and Barney Samson (2017a, 2017b), depart from a view of islands as representational or symbolic spaces, be they the traditionally self-enclosed insular spaces or the more open and hybrid spaces of counter-narratives, towards a focus on the fictional, poetic creation of islands. Thereby, they emphasise how island spaces emerge in texts through the depiction of various perspectives on them, of which the, often predominant, description of visual perceptions is only one. The authors highlight the sensual conception of island spaces in relation to sight, sound, touch, smell and taste, and they focus on spatial practices which constitute fictional islands in literature, film, advertising and computer games, thus, developing a theory of island poiesis.

From the examples of island constructions analysed in the first article (Graziadei et al., 2017a), it appears that the depicted relationship to an island is rarely that of already being there, but instead is one of arrival, discovery, travel across the sea towards the island and the - often unexpected - encounter with an 'other' space. In this way, the multi-sensory re-reading of fictional islands remains connected to established island narratives ultimately linked to colonial conquest and appropriation of island spaces from the outside. It is also related to the topical association between islands and beginnings (Deleuze, 2002): the island emerges in the text when it is first encountered; such a scene of beginning, of new discovery is characteristic of many island narratives. It, obviously, sidelines the perspective of those living on islands, and reinforces the notion of the island as a blank, uninhabited, and uncivilised space to be discovered, to be inscribed, to be conceived. As a textual conception this can, however, reflect critically on one-sided island encounters and colonial appropriations. The article shows this, for instance, with regard to Derek Walcott's Pantomime, where the creation of an island is literally staged and a reversal of dominant Western island discourses enacted when the characters play a black Robinson Crusoe and a white Friday, thus inverting hierarchies of power as well as prevailing images of the exotic linked to tropical islands. Such a deconstruction of existing island narratives and predominant, even essentialist, interpretations of islands is at the core of the second paper on island poetics (Graziadei et al., 2017b), which explores meta-fictional reflections on island conception, the intermedial 
unsettling as well as the ultimate refusal of any stable island creation in various texts and films. Highly self-reflexive literary texts, such as Umberto Eco's The Island of the Day Before (1995) and Adolfo Bioy Casares' The Invention of Morel (1940), are analysed alongside the television series Lost (2004-2010), for instance, showing how in these different medial constructions of islands, preconceived notions of islandness are destabilised and the multi-layered, intertextual and intermedial, dynamic poetics of island conception becomes apparent. This island poetics entails a constant reinvention and meta-fictional reflection on island making in aesthetic productions but also in other island discourses as well as spatial practices related to islands.

In 'Dreaming of Islands: Individuality and Utopian Desire in Post-Darwinian Literature', Niall Sreenan (2017) links the island topos to central notions of Western thought: individual autonomy and the idea of a human biological independence, which - despite the broad acceptance of Darwin's insights into evolutionary interrelations - maintains a clear demarcation between the human and the non-human animal. Sreenan analyses the use of the island in literature as a space in which such autonomy can be imagined; at the same time, he shows how the idea of an absolute isolation of the island turns out to be as untenable as the concept of human independence and sovereignty. Following Deleuze's seminal text Desert Islands (2002) and his reading of Robinson Crusoe, the island is analysed in its function as a site for the dream of the autonomous, sovereign agent who is at the centre of liberal capitalist ideology. However, just like the island is constituted by the very instability of the boundary between land and sea, the autonomous individual is revealed in its relational and dynamic constitution through a constant process of differentiation; its autonomy and its stability are illusionary. In the same way, after Darwin, what is human is not a fixed biological or ontological reality, but rather a continually shifting position in a process of change. These complex philosophical reflections are then confronted with island constructions in several literary texts, such as Samuel Butler's Erewhon (1872), Aldous Huxley's Island (1962) and Michel Houellebecq's The Possibility of an Island (2007). In his readings of these novels, Sreenan also emphasises how the notion of the island as a paradigmatic site of dreams of independence, of the individual or the human species, is undermined by the island's own relational and dynamic constitution: the seemingly isolated island, like the seemingly autonomous human, is always linked to its other, in time and space, it is part of an interconnected process of becoming rather than being a self-enclosed, stable entity.

It would be worth enquiring into the relationship between the island as a topos of the autonomous subject - the predominantly male traveller, discoverer or coloniser in island fictions - and a general pattern of gendered island discourses. It seems that women tend to appear as the, often mythical, enticing or longed-for, inhabitants of islands, starting with Circe and Calypso, for example, but rarely, just as in other traditions of travel literature, as their explorers, not even in the alternative island narratives considered here, such as the novel The Invention of Morel by Adolfo Bioy Casares (Graziadei et al., 2017b) with the female character Faustine as part of an artificially recreated projection of a past island life, or the computer game Dear Esther (Graziadei et al., 2017a), where the woman named Esther is an absent memory on the island, its explorer a male character. While the conception of islands is shown to be highly varied and multi-layered in contemporary literature and other media, one could ask whether the gender pattern of island narratives does not remain far more limited and clichéd. As discussed below, the article by Smith et al. (2017) in this thematic section offers a reading of an island novel which constructs an island as a space for experimentation with gender roles. The further study of gendered island discourses is one of many questions for future research in island literature studies.

\section{Islands in German-language literature}

Reflecting the increased dedication to island fictions and metaphors in German-language literature as well as in German studies over the last decade, two important contributions to this thematic 
section discuss German-language narratives, both from a historical-imagological as well as a deconstructive perspective.

In her article entitled 'Island Geopoetics and the Postcolonial Discourse of Sardinia in German-Language Literature', Valentina Serra (2017) gives an overview of Sardinia representations in German literature since the 18th century, proving an intriguing development in the literary discourse about the island from the construction to the deconstruction and eventually replacement of island myths. With Sardinia being an island which has inspired many German-speaking travellers and writers over time, Serra shows that the literary take on the island in the 19th century changed from a hegemonic view on the Other as place of wilderness and primitivity - such as in Alfred Meissner's Durch Sardinien (1859) - to a source of inspiration as well as of fears and desires in Baron Heinrich von Maltzan's Reise auf der Insel Sardinien (1869). In the beginning of the 20th century, the Italian island is then increasingly perceived as a place where nature and culture merge into a relationship of perfect harmony, developing from an island as object of description to an island of narration and being inscribed with an unearthly island myth as place of 'mystical communion' between reality and fantasy. In this manner, the island becomes the site of longing for people in search of a perfect fusion with nature and a space of belonging, representing a genuine home far from the acceleration of life, untouched by the developments on the mainland. Moreover, Serra draws on the communicative functions of islands, showing that Sardinia representations of the second half of the 20th century challenge Eurocentric perspectives and constructions of centre and periphery due to their mediating function of binary concepts in Western island discourse. In contrast to this, contemporary narratives of Sardinia move away from the island as mythical place of inspiration to rather realistic takes on the isle, deconstructing the image of untouched nature by referring to the island's present challenges of pollution, tourism and 'neo-colonization'. This culminates in Serra's discussion of the recent novel Mein Sardinien (2012) by Hans-Ulrich Treichel, which, on a meta-textual level, represents an attempt at deconstructing literary Sardinia myths by ironically drafting an island devoid of any stereotypical features of the Mediterranean, such as cypresses, the palaces or even the sea.

Oriana Schällibaum's paper 'Narrating Islands: Fragmentation and Totality as Figures of Thought in Raoul Schrott's Work' (2017) discusses two contemporary novels by Austrian writer Raoul Schrott, in which islands are not only represented but also employed as structure to his texts. Schällibaum shows how Schrott's novels offer different concepts of islands and therefore explore, contribute to and challenge the discussion about Western island discourse in an interesting way. In Tristan da Cunha or Half of the Earth (2003), Schrott questions the common notion of an island as paradisiac place by referring to the harsh living and climatic conditions, but most of all on different levels destabilises the island as the supposed centre of the text through a number of oppositional structures which lead to a fragmentation of the narrative and reveal the artificial cohesion of the island's supposed totality. This is, for example, created through Schrott's polyphonic narrative strategy which, on a textual level, creates an underlying conflict between unity and fragmentation. Moreover, Schrott's interweaving of facts and fictional elements leads to a questioning of the written text itself, and the doubling of the author's voice, containing traces of Schrott himself, repeatedly counteracts the promise for totality. Therefore, Schällibaum argues, the novel reveals an essential feature of insularity, which consists of paradoxically unifying opposites, for which islands can be seen as double entities. Similar to Tristan da Cunha, the novel Finis terrae. Manuscripts (1995) also counteracts the notion of the island as centre of the text, to the extent that any search for meaning by the protagonists and the reader ends in vagueness, culminating in a fragmentation of knowledge with the island representing the limit of the explainable. According to Schällibaum, in his novels Schrott therefore suggests thinking 'archipelagically', and by employing island representations, challenges traditional cultural concepts through fragmentation, inviting to a constant re-composition. 


\section{Island fictions as metaphors for socio-political realities}

Following these contributions on German-language literature, the two last articles in this section on island literature tackle contemporary island representations from a different angle, interpreting them as a critical discussion or reflection of socio-political discourses.

In 'Reading the Archipelago in Julieta Campos' 'The Fear of Losing Eurydice", Dani Redd (2017) suggests archipelagraphy, following Edouard Glissant's Poetics of Relation, as a productive theoretical framework for reading Cuban writer Julieta Campos' 1993 novel. Archipelagraphy proposes a fluid and flexible concept of island spaces, considering them as autonomous but at the same time part of a larger unity of islands, therefore suggesting interconnectedness and destabilizing common discourses based on the traditional opposition of land and sea. Following Redd's reading of Campos's novel, the writer employs the motif of the archipelago in order to criticise common notions of Cuba as colonizable place and to open up a new space for her own political agenda. Revealing the impossibility of fixing the island to one place, Campos drafts textual isles by including island quotations on the margins of the pages, which, also being compared to a prose of water, are open and flexible to the flow of association and language. Thereby, the textual islands can merge into each other, decentring meaning and inverting concepts of centre and periphery, as well as creating a textual hybridity. According to Redd, the notion of Cuba as a fixed, utopian space for the colonisers' ideologies and impositions is destabilised through the opening of the islands' borders into an archipelago, providing a new, rhizomatic space for alternative inscriptions and thus questioning a Eurocentric perspective on the island which considers insular spaces as peripheral and vulnerable.

The second contribution dealing with a socio-political reality by employing the motif of an island is offered by Keiron Smith, Jon Anderson, Kirsti Bohata, and Jeffrey Morgan (2017). As Julieta Campos' novel on Cuba, Twenty Thousand Saints (2008) by Welsh author Fflur Dafydd deals with a real geographic island, here the island of Bardsey situated two miles from the coast in northern Wales. Published just two years after the referendum deciding on the establishment of a Welsh Assembly Government, the novel clearly reflects the political developments in post-devolution Wales, constructed as an insular space mirroring the rising autonomy of the government. Drafting an imagined Welsh geography, according to Smith et al., the novel particularly deals with the relationship between the mainland and the island and thus the construction of Bardsey and its specific relationship with Wales. In the 'islophiliac' Welsh culture, as Smith et al. argue, due to imaginations of political autonomy, the insular is also positively charged by representing clear boundaries, thus independence and a sense of national identity. This tendency of praising the insular is prominently shown in Welsh literary history from mythological representations to contemporary Welsh prose, of which Dafydd's novel can be considered exemplary. Beyond representing the desire for autonomy, however, the fictional island in Twenty Thousand Saints is also employed as space of experimentation, inverting and questioning identities on the mainland and connecting the isle to a larger context. The island is therefore not marginalised as in common discourse, but rather shifted closer to the centre as figuration of the mainland, constantly re-negotiating and questioning its political climate. The realistic representation of Bardsey's present challenges clearly refers to Wales' socio-political reality, an aspect which is also depicted through the characters' often ironised, salient connection to the mainland. The insular thus becomes a site of instruction, also by questioning traditional gender discourses and suggesting a utopian matriarchal alternative society which provides a space for sexual experimentation and same-sex relationships. 


\section{Background}

This thematic section on Island Fictions and Metaphors in Contemporary Literature is partly based on papers presented in a panel with the same title at the 21 st Congress of the International Comparative Literature Association (ICLA) in Vienna in 2016. The panel was organised in relation to the research focus on Islands and Insularity at the Department of German, University of Malta, which started to develop with the planning of the international conference Insularity: Representations and Constructions of Small Worlds in 2013. This led to two publications, Insularity: Small Worlds in Linguistic and Cultural Perspectives (Heimrath \& Kremer, 2015) and one with the same title as the conference (Dautel \& Schödel, 2016).

\section{References}

Bauer, K. (2016). staging utopian insularity: the end of empire in Christian Kracht's Imperium. In K. Dautel \& K. Schödel (Eds.), Insularity: representations and constructions of small worlds (pp. 167-176). Würzburg: Königshausen und Neumann.

Bauer, M. (2017). Zeitinseln im Film. In H.R. Brittnacher (Ed.), Inseln (pp. 32-52). München: edition text+kritik (= Projektionen. Studien zu Natur, Kultur und Film).

Brittnacher, H.R. (Ed.) (2017a). Inseln. München: edition text+kritik (= Projektionen. Studien zu Natur, Kultur und Film).

Brittnacher, H.R. (2017b). Die Insel: Idylle und Desaster. In H.R. Brittnacher (Ed.), Inseln (pp. 7-17). München: edition text+kritik (= Projektionen. Studien zu Natur, Kultur und Film).

Brittnacher, H.R. (2017c). Die Insel: Idylle und Desaster. In literaturkritik.de. Rezensionsforum. 6 (June 2017), Schwerpunkt: Insel-Literatur. http://literaturkritik.de/die-insel-idylle-unddesaster, 23343.html

Burggrabe, H. (2016). "A triangle in the blue sea [...], and each of its sides faces a different world": Sicily as island of the 'between' in German-language literature of the 20th century. In K. Dautel \& K. Schödel (Eds.), Insularity: representations and constructions of small worlds (pp. 93-106). Würzburg: Königshausen und Neumann

Dautel, K. (2016). The power of cartography - Judith Schalansky's Atlas of Remote Islands. In K. Dautel \& K. Schödel (Eds.), Insularity: representations and constructions of small worlds (pp. 155-166). Würzburg: Königshausen und Neumann.

Dautel, K. \& Schödel, K. (Eds.) (2016). Insularity: representations and constructions of small worlds. Würzburg: Königshausen und Neumann.

Deleuze, G. (2002). Desert islands. In Desert islands and other texts 1953-1974. D. Lapoujade (Ed.) \& M. Taormina (Trans.). Paris: Les éditions de Minuit.

Dünne, J. \& Mahler, A. (2015). Handbuch Literatur \& Raum. Berlin \& Boston: De Gruyter.

Ette, O. (2011). Insulare ZwischenWelten der Literatur. Inseln, Archipele und Atolle aus transarealer Perspektive. In A.E. Wilkens, P. Ramponi, \& H. Wendt (Eds.), Inseln und Archipele. Kulturelle Figuren des Insularen zwischen Isolation und Entgrenzung (pp. 13-56). Bielefeld: Transcript.

Giacovelli, S., \& Langenohl, A. (2016). Offshore-Finanzzentren zwischen Rückständigkeit und Avantgardismus. In M. Ostheimer \& S. Zubarik (Eds.), Inseln und Insularitäten. Ästhetisierungen von Heterochronie und Chronotopie seit 1960. Ästhetische Eigenzeiten (pp. 87-101). Bd. 3. Hannover: Wehrhahn.

Görbert, J., Kumekawa, M., \& Schwarz, T. (Eds.) (2016). Pazifikismus. Poetiken des Stillen Ozeans. Würzburg: Königshausen und Neumann.

Graziadei, D. (2015). Nissopoiesis: Wie Robinsone ihre Inseln erzählen. In: J. Dünne \& A. Mahler (Eds.), Handbuch Literatur \& Raum (pp. 421-430). Berlin \& Boston: De Gruyter. 
Graziadei, D., Hartmann, B., Kinane, I., Riquet, J. \& Samson, B. (2017a). On sensing island spaces and the spatial practice of island-making: introducing island poetics, Part I. In Island Studies Journal, 12(2).

Graziadei, D., Hartmann, B., Kinane, I., Riquet, J. \& Samson, B. (2017b). Island metapoetics

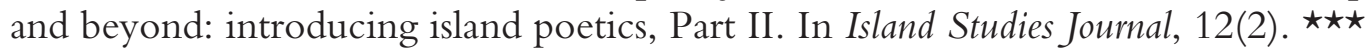

Heizmann, J. (2017). Von der Historie zur Fabula. Alcatraz im Film. In H.R. Brittnacher (Ed.), Inseln (pp. 53-72). München: edition text+kritik (= Projektionen. Studien zu Natur, Kultur und Film).

König, T. (2011). Die Entgrenzung Siziliens in der italienischen Literatur des 20. Jahrhunderts. In A.E. Wilkens, P. Ramponi, \& H. Wendt (Eds.), Inseln und Archipele. Kulturelle Figuren des Insularen zwischen Isolation und Entgrenzung (pp. 135-152). Bielefeld: Transcript.

Heimrath, R., \& Kremer, A. (Eds.) (2015). Insularity: small worlds in linguistic and cultural perspectives. Würzburg: Königshausen und Neumann.

May, M. (2017). Capri - irdisches Paradies und Friedhof der Zivilisation. Literarische Reflexe von Goethe bis Stadler. In H.R. Brittnacher (Ed.), Inseln (pp. 161-179). München: edition text+kritik (= Projektionen. Studien zu Natur, Kultur und Film).

Moser, C. (2005). Archipele der Erinnerung. Die Insel als Topos der Kulturisation. In H. Böhme (Ed.), Topographien der Literatur. Deutsche Literatur im transnationalen Kontext. DFGSymposion 2004 (pp. 408-432). Stuttgart \& Weimar: Metzler.

Ostheimer, M., \& Zubarik, S. (Eds.) (2016a). Inseln und Insularitäten. Ästhetisierungen von Heterochronie und Chronotopie seit 1960. Ästhetische Eigenzeiten. Bd. 3. Hannover: Wehrhahn.

Ostheimer, M., \& Zubarik, S. (2016b). Einleitung. In M. Ostheimer \& S. Zubarik (Eds.), Inseln und Insularitäten. Ästhetisierungen von Heterochronie und Chronotopie seit 1960. Ästhetische Eigenzeiten (pp. 7-15). Bd. 3. Hannover: Wehrhahn.

Pötzsche, J. (2017). Inselpsychosen. Über Martin Scorseses Shutter Island. In H.R. Brittnacher (Ed.), Inseln (pp. 129-139). München: edition text+kritik (= Projektionen. Studien zu Natur, Kultur und Film).

Ramponi, P., Wendt, H., \& Wilkens, A.E. (2011). Vorwort. In A.E. Wilkens, P. Ramponi, \& H. Wendt (Eds.), Inseln und Archipele. Kulturelle Figuren des Insularen zwischen Isolation und Entgrenzung (pp. 7-11). Bielefeld: Transcript.

Redd, D. (2017). Towards an archipelagraphic literary methodology: reading the archipelago in Julieta Campos' The Fear of Losing Eurydice. In Island Studies Journal, 12(2).

Schällibaum, O. (2017). Narrating islands: fragmentation and totality as figures of thought in Raoul Schrott's work. In Island Studies Journal, 12(2).

Serra, V. (2017). "Inseln sind Heimat im tieferen Sinne". Sardinia Interpretations and Myth

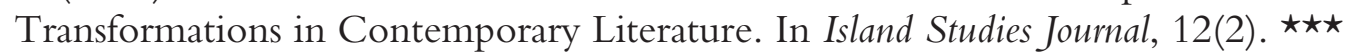

Smith, K., Anderson, J., Bohata, K. \& Morgan, J. (2017). "It'll be our own little Wales out there": re-situating Bardsey Island for post-devolution Wales in Fflur Dafydd's Twenty Thousand Saints. In Island Studies Journal, 12(2).

Spanke, K. (2017). Die Unmöglichkeit einer Insel. Über die Fernsehserie Lost. In H.R. Brittnacher (Ed.), Inseln (pp. 96-115). München: edition text+kritik (= Projektionen. Studien zu Natur, Kultur und Film).

Sreenan, N. (2017). Dreaming of islands: individuality and utopian desire in post-Darwinian literature. In Island Studies Journal, 12(2).

Termeer, M. (2011). Isolationen. Von lieblichen Orten und Habitatinseln, oder: der locus conclusus als Paradigma gesellschaftlicher Naturbeziehungen. In A.E. Wilkens, P. Ramponi, \& H. Wendt (Eds.), Inseln und Archipele. Kulturelle Figuren des Insularen zwischen Isolation und Entgrenzung (pp. 209-224). Bielefeld: Transcript.

Wilkens, A.E., Ramponi, P., \& Wendt, H. (Eds.) (2011). Inseln und Archipele. Kulturelle Figuren des Insularen zwischen Isolation und Entgrenzung. Bielefeld: Transcript. 
Katrin Dautel \& Kathrin Schödel 